\title{
The rise of a Latin model? Family and fertility consequences of employment instability in Italy and Spain
}

Paolo Barbieri, Rossella Bozzon, Stefani Scherer ${ }^{1}$

with Raffaele Grotti and Michele Lugo

Department of Sociology and Social Research, University of Trento, Italy

\begin{abstract}
This paper analyses how unstable employment influences becoming a mother in Italy and Spain. Results suggest that institutional factors foster dynamics of social inequality and hinder family formation. We show that in southern Europe (Italy and Spain), but not in other institutional contexts, the lack of employment stability produces a delay in fertility decision. We attribute this impact of the employment situation on demographic decisions to the subprotective southern European welfare systems and the insider-outsider labour market configuration, as enhanced by the partial and targeted labour market deregulations of recent decades. In the context of low levels of welfare, unstable employment often comes with persistently reduced entitlement to social and welfare rights, and, therefore, with notable social and demographic consequences. We provide support for this institutional argument by showing that fertility decisions are independent of employment stability in other contexts. Analyses are based on longitudinal data using event history analysis and simultaneous equation models.
\end{abstract}

Key words: welfare and labour market, employment precariousness and family formation, insider-outsider divide.

\footnotetext{
${ }^{1}$ Authors acknowledge financial support from the European Research Council under the European ERC Grant Agreement no StG-263183 (Families of Inequalities).
} 


\section{Introduction}

Over recent decades, European labor markets have undergone transformations which instigated a severe process of labor market segmentation, with the secondary sector characterized by the diffusion of different forms of nonstandard and precarious jobs, growing uncertainty, and instability (particularly for young labor market entrants) and high unemployment risks. The increased insecurity at career start is a direct consequence of the way in which the process of labor market flexibilization has been conducted within European labor markets (Barbieri 2009) and the aggregated consequences of the extent and type of labor market (de)regulation, depending on the welfare system (Esping-Andersen 1999; Mayer 2004). The most problematic social consequences of this process have been found in corporatist-conservative systems, and specifically in southern Europe, where the rapid and intense shift from rigid employment protection systems to labor markets which are flexibilized (only) 'at the margins' propelled

the so-called insider-outsider divide (Esping-Andersen and Regini 2000; Blanchard and Landier 2002; Blossfeld et al. 2008; Barbieri 2011). The interaction with individual characteristics and endowments produces specific structures of (dis)-incentives for different 'biographical breaks' (Vandecasteele 2011).

In addition, the 'demographic crisis' has hit southern Europe particularly hard. The sharp decline in fertility rates among advanced countries began in the mid1970s - well before the launch of the process of labor market deregulation - due to a combination of increasing age at first maternity (tempo effect) and a decline 
in the number of children per woman (quantum effect). Italy and Spain have experienced a significant postponement of first births without catching up in number as women age (Frejka and Sobotka 2009; Billari 2008; Bratti and Tatsiramos 2012). Other Western countries also have a fertility rate way below the replacement rate, but did not reach these "lowest low" levels.

This paper brings together the increasingly insecure employment situations and fertility decisions and investigates how specific episodes in women's work careers - work insecurity and precariousness - influence the timing of first childbirth. The issue is particularly relevant in low-fertility countries, where it meets a pre-existing trend of fertility reduction. We argue that, following an institutionalist approach to family formation (Smeeding et al. 2004) the relevance of employment for fertility decisions has to be understood in terms of the relation between macro-level welfare support, labor market arrangements, and microlevel, individual characteristics, including work histories. The lack of institutional support combined with a segmented labor market structure not only leads to increased levels of employment uncertainty, but also increases the opportunity costs of motherhood for non-stably employed women (Blossfeld, et al. 2005; Billari 2008) and thus (further) reduces fertility. We analyze the impact of employment instability and the mediating effect of personal resources on women's fertility dynamics, focusing on a context that provides weak institutional support for young people (in terms of unemployment protection, 
active labor market policies and welfare benefits) and newly formed families ${ }^{2}$ and is characterized by a strongly segmented labor market - namely Italy and Spain. We compare these results to countries with different macro contexts namely Germany and the USA - to provide additional support for our institutional argument. The effect of employment insecurity is expected to be much less pronounced, or even absent, in contexts that either provide institutional support (Germany) or are characterized by more fluid and efficient labor and service markets (USA). We show that southern Europe show a particular pattern and provide arguments for why this is the case.

The next section presents the institutional arguments regarding the link between employment and reproduction and reviews the empirical literature. Section 3 then presents the specific contribution of this paper. Data and methods are treated in section 4, section 5 reports the results, and section 6 concludes.

\section{Childbirth in southern Europe and the role of employment stability}

The classic microeconomic approach identifies the growth in women's economic independence as the primary cause of the fertility crisis. In this view, the

\footnotetext{
${ }^{2}$ We consider Italy and Spain, in line with main labor economic and sociological literature, as two institutionally rather similar countries (Bratti and Tatsiramos 2012). We do not enter in a detailed comparison between the two countries on specific aspects, as this is not necessary for our line of argumentation. For the debate see Martín-García (2013) and Naldini and Jurado (2013).
} 
declining number of children per woman is due to the growing opportunity costs of child-bearing and child rearing for women likely to participate in the labor market (and trying to balance work and family roles). Empirical studies confirm that especially highly educated women have strong incentives to invest in their careers before having children because their employment chances and their returns on education decrease with maternity (Baizan 2005; Barbieri and Scherer 2008). Comparative studies have noted the relevance of institutional settings in providing opportunities that enable women to combine childbirth and employment (Bratti and Tatsiramos 2012; Ahn and Mira 2002; Gauthier 2007; Sleebos, 2003). Rindfuss and Brewster (1996) argued that if female labor force participation acts as a constraint on fertility, any easing of the worker-mother conflict, such as improvements in childcare quality and availability, as well as any decrease in the cost of childcare, would have a positive impact on fertility. Bratti and Tatsiramos (2012) examining childbirth in European countries find a postponement effect in countries where the opportunity cost of childbearing is relatively high due to the lack of family friendly institutions, side by countryspecific cultural influences. Countries are, thus, differently equipped to ease potential work-family frictions. Ferrera (2010) maintains that the southern European welfare state is particularly unfit in this respect and is further unable to compensate for growing labor market insecurity - affecting mainly the young cohorts in their "fertile years" - due to its typical 'double distortion' toward oldage transfers and insider protection. This prevents from the adoption of forms of social policies able to help women to reconcile work and family duties and shelter 
young families from economic insecurity. ${ }^{3}$ Indeed, Italy and Spain are both known to offer minimum state support to families, both in terms of services and transfers. Care responsibilities are relegated to the domestic environment, i.e. 'endogenized' into the family (Esping-Andersen 1999; Gauthier 2007, Keck and Saraceno 2013, 2010, Saraceno and Keck, 2011) and (official) market solutions are disincentivized. ${ }^{4}$ Public child and elderly care services are scarce, the taxation systems disfavor families, family benefits are among the lowest in western Europe, and parental leave is comparatively long but unpaid (González 2006; Del Boca and Wetzels 2007). Such welfare shortages make (stable) employment in general particularly relevant for family formation, and in particular they increase the opportunity costs associated with motherhood - especially for women with high human capital endowment. As a consequence, Italian and Spanish working women are 'structurally' forced to maximize their career opportunities before becoming mothers (Golsch 2003; González 2006; Scherer and Reyneri 2008) and are thus likely postpone motherhood.

\footnotetext{
${ }^{3}$ Old-age and insider biases strongly overlap: Pampel (1994) suggested that national institutional arrangements influence the intergenerational distributional clash, which becomes harsher in countries where insiders and pensioners lobbies succeed in affecting pension reforms. EspingAndersen and Sarasa (2002) showed that the age-bias is especially pronounced in Continental and southern European insider-outsider assets, while Scandinavian social democracies are more youth-biased.

${ }^{4}$ Saraceno and Keck (2011) spoke about "familialism by default" referring to the Mediterranean situation.
} 
This situation interacts with the process of labor market flexibilization, which in Italy and Spain took the form of a strong partial and targeted deregulation. Deregulation at the margins, planned to respond to widespread unemployment, significantly reduced both labor and welfare protections, thus exacerbating the gap between labor market insiders and young outsiders (Barbieri 2011; Barbieri and Scherer 2009; Polavieja 2003, 2005; Bentolila et al. 1994). The negative effects of these processes concentrate on the young, recent labor market entry cohorts, and women (Esping-Andersen and Regini 2000; Blossfeld et al. 2008; Barbieri 2009). The young experience more difficulties than previous cohorts with finding secure employment conditions and are increasingly exposed to higher risks of unemployment and employment instability, thus with increasingly unstable and fragmented working careers. Education moderates the effects of labor market flexibilization. Temporary contracts may serve as a stepping stone for (part of) the better-educated workers (Barbieri and Scherer 2009), whereas the poorly educated are more likely to be limited to precarious employment in the secondary labor market.

Various studies document how the persistent wage penalty of contingent work (compared to permanent work) and the consequent loss of potential earnings of young cohorts of instable workers helped to expand labor market segmentation and dualism in southern Europe (Davia 2004; Rosolia and Torrisi 2007; Barbieri and Cutuli 2010; Cutuli and Guetto 2013). Therefore, the southern European model faces increasing difficulties to offer the type of secure employment necessary for a one-breadwinner equilibrium in which the family is guaranteed 
access to welfare support as a result of the (male) head of household's secure job; the increased labor market uncertainty enhances the relevance of a second income for the future economic well-being of the family. As a consequence, a woman is likely to delay becoming a mother until she has reached an economically stable employment situation (González and Jurado-Guerrero 2007).

Previous studies focusing on the interrelation between women's employment, their work careers (including unemployment and insecure work experiences) and family formation in Italy and Spain yield inconsistent results. Some studies report that the persistence of the traditional male breadwinner model among Italian and Spanish families implies that the rise of work uncertainty appears to affect only men's family formation and parenthood, whereas among women the main distinction is between jobless women (who are more likely to marry and have children) and employed women. According to these studies, flexible work arrangements do not play any significant role in postponing women's family transitions (Bernardi and Nazio 2005; Vignoli et al. 2012; Golsch 2003) and Golsch (2003) found the probability of becoming mother to be highest among women with weak labor market attachment. In contrast, other studies showed that among Spanish women rising instability (unemployment and temporary contracts) leads to the postponement of marriage, indirectly affecting fertility (Gutiérrez-Domènech 2006). Finally, de la Rica and Iza (2005) noted that among young women with temporary contracts, motherhood is delayed independently of the husband's employment contract. Friedman et al. (1994) and Kreyenfeld 
(2010) underline that the role of employment security might be moderated by women's characteristics and endowments and they report evidence that among low-educated women, economic uncertainties accelerate the decision to have children (Kreyenfeld 2010). However, this previous research is largely based on data from the 1990s, when the process of labor market deregulation was in its very early stages in Italy. In Spain, the process began more than a decade earlier, which may explain the differences between the various studies. This paper integrates previous evidence using a more ample time window to analyze changes in demographic behavior and its dependence on the employment situation within the context of increasing levels of economic and employment uncertainty. We focus on the effects of unstable ${ }^{5}$ or even precarious employment positions on women's transiting to parenthood.

\footnotetext{
${ }^{5}$ We use the terms 'atypical', 'flexible' and 'unstable' as synonyms.
} 


\section{Research questions - this paper's contribution}

Italy and Spain are fairly similar regarding these macro-level institutional factors, namely the "familistic" sub-protective welfare and the type of labor market (de)regulation. We argue that the combination of these institutional contexts increases uncertainty in the initial phase of adult life and thus hampers family formation, mainly for those in secondary labour market positions. We expect that in this southern European context job uncertainty and/or atypical/precarious jobs at early career stages lead to a delay of motherhood (Hypothesis 1-a). Yet, once a stable employment position is gained and/or secure economic conditions have been reached the likelihood of having a child should then increase (H1-b). This paper does not intend to explain either fertility trends in general, or the differences between countries in fertility levels. It focuses on the effect of instable employment situations on motherhood in Italy and Spain, as an institutionally originated and defined phenomenon.

Women's education is expected to play a key role in moderating the effects of unstable careers, in the sense that the delay of first birth through secondary labor market positions should be much stronger among more highly educated women (H2). The reason is twofold. First, the potential depreciation of the career by motherhood is higher among highly educated women. Second, these women have greater chances to escape from disadvantageous employment positions and achieving an 'adequate' career level and/or contractual position that is then (perceived as) compatible with having a child. It is thus rational to postpone motherhood until this happens. The situation might be different for less-well 
educated women, for whom precarious employment may even speed up motherhood. According to Friedman et al. (1994), for women with very limited career prospects the alternative role as a mother and thus a rapid family formation might be appealing, and a strategy to reduce uncertainty in their life. ${ }^{6}$

Usually, the decision to have a child is taken within a couple and therefore influenced by both partners' labor market conditions. In general, living with a partner certainly increases the chances of having a child and also the male partner's employment situation is supposed to be rather relevant (H3-a). His weak attachment to the labor market - either due to unemployment or unstable employment - should reduce childbirth. Given the increasing importance of dualearner family arrangements for the family's future wellbeing (also due to the general diffusion of economic and employment uncertainty) we expect that the

\footnotetext{
${ }^{6}$ Friedman et al. (1994) sustain that rational actors will regularly prefer the conditions that allow them to reduce the level of incertitude they experience in their life course. In this view, prospects for stable and successful careers will have a negative effect on the propensity for parenthood, because achieving a good work position represents a more effective way of reducing personal uncertainty than motherhood - for those who actually have these prospects, i.e. highly educated women. Those who face greater uncertainty in their work careers with little chance of improving their situation or with reduced access to other means of reducing uncertainty, i.e. the less-well educated, may choose parenthood as a strategy to structure their otherwise uncertain life course (Kreyenfeld 2010) and thus earlier motherhood decisions are a response to uncertain employment.
} 
effect of the woman's employment condition and career enhancement should be at least as relevant as her partner's ones (H3-b).

As noted, this paper focuses on the specific southern European context. Yet, to provide empirical support for our macro-argument that it is the specific combination of the 'Latin' welfare-and-labor-market arrangement that produces the outcomes of employment insecurity on fertility decisions (on the micro level), we include two different cases. The first is Germany, a continental welfare state, similar in some respects to the southern European countries, but different in others. Despite the same "insurance-based welfare model", the support available to families through services and transfers are generally much higher and the segmentation of the labor market follows skills rather than a cohort/age line. The second case is the United States, similar to Italy and Spain with regard to the almost absence of a welfare state but very different in terms of labor market fluidity and employment creation capacity. The U.S. in fact is among the most 'efficient' and mobile markets. If our argument about the combination of institutional assets is correct, we should find very limited or no negative effects of unstable employment careers on fertility decisions for these countries (H4).

\section{Data and variables}

In addition to data from the five panel waves (1997-2005) of the Longitudinal Survey of Italian Families (ILFI - Indagine Longitudinale sulle Famiglie Italiane) we also drew on the Spanish Survey on Fertility and Values (FVE - 
Fecundidad y Valores en la España del Siglo XXI) conducted in Spain in 2006 by Cis (Centro de Investigaciones Sociologica), where education, work careers, and family dynamics were collected retrospectively on a monthly basis. ${ }^{7}$ For Germany we used SOEP data - a prospective panel conducted yearly - from 1984 to 2008; for the U.S. we referred to PSID data - from a prospective panel with annual measures of the employment situation ${ }^{8}$ - using waves from 1979 to 2009. To minimize recall errors and to homogenize women's employment trajectories, we considered only women born from 1951 to 1980 . Episodes start at age 15 and end with first childbirth or at the age of 45 or at the date of the interview. Because children are typically planned in advance, all time-varying variables are measured 12 months prior.

Work careers are described using three time-varying indicators: work arrangement, occupational class, and an indicator for the transition from an unstable to a permanent employment position. The classification of work arrangements included various aspects of the employment position. We draw on

\footnotetext{
${ }^{7}$ In the Spanish database, minor problems were encountered with starting and ending dates for job episodes. For the $8.03 \%$ of women with work experience (as gathered in our subsample), we have no information on the timing of the work career. We signal these cases with a dummy ="no information on the timings of work career". For approximately $5 \%$ of the job spells in the entire sample, only the starting date was available. Thus, the ending date was imputed based on the estimated median duration given the type of contract. Excluding these missing cases from the analyses did not produce significant differences in our results.

${ }^{8}$ The survey was conducted yearly until 1997 and then every two years.
} 
detailed information regarding the type of employment (dependent or selfemployment), the type of contract for dependent workers (permanent, fixed-term, training contract, seasonal, off-the-books), the type of self-employment (with or without employees, freelancer, entrepreneur), whether the work was seasonal or occasional, and the specifics of the occupation based on four-digit ISCO codes, when available. We distinguish four types of employment situation: permanent employment, self-employment, atypical employment, and other 'non-standard' jobs (mainly seasonal and off-the-books). Permanent wage workers and the selfemployed are two groups that, as shown elsewhere (Barbieri and Bison 2004), have similarly stable labor market trajectories in southern Europe. Atypical employment is represented by fixed-term workers and (only for Italy) pseudoself-employed workers; i.e. those workers who perform tasks on a self-employed basis in subordinate positions (consultants and freelancers). A standard social class schema (EGP of the individual, time-varying) is employed as a proxy of more general economic well-being. For comparability reasons, unemployment and inactivity episodes are collapsed into a residual category called 'out of work'. The data allow controlling for the presence of a partner through the woman's entire observed life course. However, the partner's occupational information refers to the partner at the time of the interview. As 'couple stability' in Mediterranean countries is still relatively high, the distortion should be limited. In the Spanish data, the male's work situation is measured only at the time of the interview, whereas in the Italian data it was possible to retrospectively reconstruct the present partner's work career. We control for partner's 
occupational characteristics, namely social class and work arrangement and their possible effects on childbirth. To rule out endogeneity of marriage and first childbirth, as suggested in the literature (Gutiérrez-Domènech 2006), we also replicated the analyses for a sample of women who had already been in a partnership at least one year before the first birth -without notable changes.

Our analysis excludes the period of the financial and economic crisis and thus avoids the risk of our results being distorted by these unfavorable developments. To consider previous business cycle effects, models control for youth unemployment rate $(15-25$, OECD data) at the country level, which is highly sensitive to economic fluctuations (EU, 2013). In general, high unemployment levels reduce the (expected) welfare of the population through employment uncertainty and lower expected income (Adserà 2004). It thus negatively affects fertility decisions. ${ }^{9}$

Controls include socio-demographic characteristics (age, age squared, birth cohorts, region of birth (NUTS), and the number of siblings at age 14), labor market entry cohort, area of residence, social class (measured at first job), level of education based on the Casmin scale, and an indicator of having left the

\footnotetext{
${ }^{9}$ As expected, adverse macro-economic conditions - namely, labor market inefficiency and lack of economic growth and job creation, as proxied by high youth unemployment rates - negatively affect the process of family formation. The influence of youth unemployment rates on the transition to the first child is persistently negative in our models, independently of all controls.
} 
educational system. ${ }^{10}$ The relevance for demographic dynamics of the latter is well established and reflects a substantial incompatibility between enrollment in education and setting up a family (Blossfeld and Timm 2003, Golsch 2003). Education is measured at the time of the interview ${ }^{11}$ which is still appropriate for Italy and Spain, where life-courses are still quite standardized sequentially (Hoem and Kreyenfeld 2006) and coming back to education later in the lifecourse is very uncommon (Barbieri et al. 2014).

We employ discrete time event history models (Yamaguchi 1991) to estimate the effects of the labor market and work status on first childbirth. For the analysis of the overall family situation, we estimated simultaneous probit models on the likelihood at age 30 of having $i$ ) a partner and ii) a child. Previous research has shown a significant positive correlation between the underlying dynamics of fertility and marriage choices (Baizan et al. 2003). Simultaneous models allow taking into account the interrelation of the two outcomes. We investigate the (negative) effect of a "precarious employment history" (the "atypical employment carousel"), which means either having spent at least three years in

\footnotetext{
${ }^{10}$ Controlling for educational enrolment alters the effects of age, education, and partnership; however, variables are not collinear.

${ }^{11}$ In the Italian database, information is available on education. We estimated models using education both as time-varying and time-invariant covariates. The results do not change significantly. For comparability issues, we used time-invariant covariates for education.
} 
atypical contracts or having accumulated at least three job episodes with unstable contracts.

\section{Results: the rise of a Latin model}

Figure 1 shows the predicted probabilities of becoming a mother for various employment situations and shows clearly that women's unstable employment reduces fertility.

Figure 1 about here

In both southern European countries, as expected (H1-a) women with atypical employment contracts are significantly less likely to enter maternity, with the distance to permanently employed women being particularly pronounced (and statistically significant) in the typical reproductive age range. This underlines the work-family trade-off concentrated on the less protected working women in southern Europe. Yet, these fertility differences among women's employment situations are not found in Germany or the US, confirming our expectations about the importance of the institutional context $(\mathrm{H} 4)$ and the effectiveness of what we labelled a "Latin" model of welfare-labor market-fertility interaction.

In the following, we discuss the specific micro determinants of becoming a mother (Table 1). The well-known progressive delay of maternity over cohorts is also confirmed by our models. In Italy and Spain the youngest cohorts of women are clearly less likely to enter maternity, also after controlling for age. Change over cohorts is more gradual in Italy, whereas in Spain the 
decline/postponement of motherhood is particularly pronounced for the youngest cohort.

Table 1 about here

The cohort effect interacts with the influence of employment insecurity on women's fertility behavior, with minor differences between Italy and Spain. As expected, being atypically employed has a negative effect on women's transition to maternity in southern Europe, and this effect is particularly strong for the youngest Italian cohorts (1971-80), whereas in Spain, the interaction between birth cohorts and atypical employment, although of the expected sign, does not reach statistical significance.

Cohort effects thus prevail in Italy while in Spain, where the deregulation began a decade earlier, the delaying effect of employment in the secondary labor market is moderated by women's individual human capital and is stronger among women with secondary and tertiary education. ${ }^{12}$

\footnotetext{
${ }^{12}$ Although the overall impact of employment flexibility is rather similar between Italy and Spain, we observe a different set of micro mechanisms at play in the two countries, affecting the speed of the transition to maternity. This underlines the differences between the two countries, which may well be due to different timings in the deregulation processes, different economic and labour markets dynamics, etc. which we cannot analyze in more detail here, given the limited number of cases.
} 
A positive effect of the stabilization of women's working conditions (transition from atypical employment to a permanent position) is confirmed in both countries (H1-b). Entering the primary, guaranteed, labor market strongly increases the likelihood of motherhood in Italy, also after controlling for the presence of a partner. The effect is less robust for Spanish women.

In both countries, individual economic conditions, as approximated by the woman's social class position, play an important role in supporting fertility decisions. This effect is particularly robust in Spain, where, controlling for education and its interaction with work arrangements (Model 2), highly qualified and service-class working women demonstrate faster transitions to the first child than do lower-class working women.

Coming to the role of women's education as key factor of the work-family balance, our data confirm the general expectation that higher education is associated with later transition to maternity. The delay, as expected in $\mathrm{H} 2$, is even stronger when holding an atypical or no employment position. In particular in Spain, highly educated women who are either precariously employed or out of work are found to postpone their transition to motherhood, while non-working low-educated women show higher chances of becoming a mother sooner. Thus, well-educated women delay maternity even more when they are in poor or insecure employment positions, whereas less well educated women seem more inclined to assume a traditional family role. This role of education is confirmed in Italy for tertiary educated women in precarious positions or out of work, although the interaction effect is slightly less stable across different formulations 
of our models (Table 1, Model 2 vs Model 3). Overall, for these two countries the results are consistent with both the independence hypothesis and with Friedman's hypothesis (Friedman et al. 1994) concerning the connection between education, the experience of labor market uncertainty, and fertility behavior. ${ }^{13}$ Thus, education plays a crucial role for fertility decisions and moderates the effects of unstable employment positions on women's fertility behavior. Interestingly, limiting the analyses to women living with a partner does not alter the role of education (Table 2): a better educated woman, independently of the presence of a partner and his employment and economic situation, delays motherhood when she is precariously employed or out of work (interactions in Table 2) while this is not the case if she is not a secondary labour market worker (as the main effects of education, reported in Table 2, refer to women not in an atypical position): in Italy, tertiary educated women not employed in the secondary labour market, enter motherhood even more quickly.

Table 2 about here

Results also support the expectations about the relevance of the partner's presence and his employment situation (H3-a). A non-employed partner appears

\footnotetext{
${ }^{13}$ Education appears to be of no relevance at all in the United States, whereas the results for Germany are rather similar to those reported for Italy and Spain, with the exception that atypical employment does not affect fertility decisions for any of the educational levels.
} 
to be an obstacle to a woman's motherhood (Tab 2). In both countries, male nonemployment undermines the capacity of the entire household to reach a stable economic situation. Our results are congruent with the findings of other studies on the role of the male's employment situation for the family in sub-protective welfare systems and the postponement of fertility decisions coming with uncertainty (Oppenheimer et al. 1997). ${ }^{14}$

Yet, once the partner is present the scarring effects of her career situation (Table 2 vs table 1) considerably diminish in Italy, i.e. for women with a partner at t-2 years. This is attributable to the fact that marriage and childbirth almost coincide, at least for the youngest cohorts, as well documented in the literature (Baizan et al. 2003, Blossfeld, et al. 2007); timing of marriage and first child is less linked in Spain. Nonetheless, in Italy, the negative effect related to atypical jobs for the youngest cohort of women (interaction between having an atypical job and 19711980 cohort in table 2 ) and the positive effect of a woman transiting to a secure work position, are reconfirmed.

To complete the picture, we now consider the possible scarring effect of an unstable (and precarious) employment history and show whether and how women's prolonged employment uncertainty comes with an "incomplete family formation", that is singlehood and/or childlessness at age 30 . We define as

\footnotetext{
14 We observe that, in Italy, families where the male partner is employed as an informal or seasonal worker (the "other" category) seem to be faster in becoming parents: a result that, most likely, is due to specific characteristics and situations of these persons.
} 
'entrapped' in a secondary labor market those women who have spent at least three years working with atypical contracts ${ }^{15}$ or who had three or more episodes of atypical employment before the age of 30 ; in this way approximately $8 \%$ of our sample result 'entrapped'. Obviously, the analysis is limited to women who entered the labor market. Results in table 3 confirm that women's chances of having a partner and/or child(ren) at the age of 30 are strongly negatively associated with precarious careers 'entrapped' in the secondary sub-protected labor market. To ease interpretation, table 4 presents the predicted probabilities (based on models in table 3) of living in a couple and/or being a mother at the age of 30 , for different profiles of women. Differences in the predicted probabilities are rather pronounced and similar in both southern European countries. Only approximately $40 \%$ of women with precarious careers have both a partner and child(ren) at age 30 , compared to about $55 \%$ of women with more stable careers. And even when living in a partnership, their probability of having a child are significantly lower than for women with more stable careers. Evidently, precarious employment situations hinder family formation and fertility in southern Europe. That this is not necessarily the general case, but depends on the specific 'Mediterranean' situation emerges from the comparison with Germany and the US, where there is no such negative effect whatsoever. On

\footnotetext{
${ }^{15}$ The median duration of a spell of "atypical employment" for women is 22 months in Italy and 19 in Spain.
} 
the contrary, in part we even observe faster family formation for non-standard paths (Table $4 \mathrm{~A}$ in appendix). ${ }^{16}$

Tables 3 and 4 about here

\section{Conclusions}

This paper focused on the consequences of employment insecurity on fertility decisions in Italy and Spain and also on the consequences of increased labor market deregulation. Results confirm that in these countries atypical employment experiences (either being precariously employed or having being locked in the secondary labour market) reduce the probability of becoming a mother. In Italy, this is particularly true for the youngest cohorts of women, which are affected by the diffusion of employment instability or even prolonged precariousness through increased labor market de-regulation.

In this sense, labor market flexibilization in the 'Latin' countries had serious demographic consequences and led to postponed motherhood. In addition, the negative influence on fertility of atypical employment, as well as of nonemployment, is mainly concentrated on highly educated women (in Spain also

\footnotetext{
${ }^{16}$ In the case of the US and Germany it is likely that (part) of this finding is due to a self-selection of less employment-oriented women in secondary labor markets. In Mediterranean countries, where institutional determinants prevail over individual traits, i.e. risks for atypical employment are very much institutionally structured, unobserved heterogeneity should be less of an issue.
} 
on those with medium levels of education), while less well educated women, especially when unstably employed, seem to opt for motherhood much sooner. The career prospects tied to women's human capital endowment thus appear to play a decisive role for the timing of the first birth in southern European countries. We consequently find confirmation for the main hypothesis regarding the negative impact of employment instability on demographic transitions and the moderation of this effect by human capital of the women. Confirmation that we are observing purposeful delay also comes from the fact that transiting to a secure employment position strongly increases the chance of becoming a mother, especially in Italy. In the Mediterranean context, the presence of an employed partner positively affects transition to motherhood. Though the partner's employment appears to be a prerequisite for parenthood, his social class does not play a significant role, while a woman's mid-high social class clearly supports transition to motherhood. The analysis therefore supports the idea of an increasing relevance of a dual-earner family equilibrium for economic wellbeing (Daly 2013, Esping-Andersen et al. 2013), with the effect of women's employment and occupational conditions becoming increasingly relevant not only for the general household situation, but also for the economic and demographic equilibria of society.

We argue that this negative spillover of employment instability on family formation has institutional origins and is rooted in the insider-outsider configuration of welfare and labor market arrangements. The combination of a sub-protective welfare system characterized on the one hand by only residual 
support to young persons (who are thus in their family formation period) and insurance-based social rights, but with a strongly segmented labor market on the other hand, makes employment instability an inhibitor for setting up a family with severe long term consequences for demographic aging, not to mention other relevant societal inequality aspects, like gender disparities. These negative effects on fertility have been exacerbated by the partial and targeted labor market deregulation. We provide empirical support for the claim on the macro context by showing that neither in Germany - a country with segmented labor market but more generous welfare, nor the United States - a country with residualistic welfare support but a more flexible labor market, does employment insecurity/precarity have any negative effects at all on motherhood. Numerous studies have emphasized the importance of institutional factors for employment and for family formation, underlining also the mutual embeddedness of labor market and welfare state. We have shown that southern Europe displays a specific pattern which is due to the lack of welfare support in combination with labor market segmentation. In this context, we have shown that employment instability also comes with significant demographic consequences. 


\section{References}

Adserà, A. (2004) 'Changing fertility rates in developed countries. The impact of labour market institutions' Journal of Population Economics 17: 17-43.

Ahn, N. and Mira, P. (2002) 'A note on the changing relationship between fertility and female employment rates in developed countries', Journal of Population Economics 15: 667-682.

Baizan, P. (2005) 'The impact of labour market status on second and higher-order births A comparative study of Denmark Italy Spain and United Kingdom', DemoSoc Working Paper 11: 1-28, http://www.upf.edu/demosoc/_pdf/DEMOSOC11.pdf

Baizan, P., Aassve, A. and Billari FC (2003) 'Cohabitation marriage and first birth: The interrelationship of family formation events in Spain', European Journal of Population/Revue européenne de Démographie 19: 147-169.

Barbieri, P. (2009) 'Flexible Employment and Inequality in Europe', European Sociological Review 25(6): 621-628.

Barbieri, P. (2011) 'Italy: no country for young men (and women)', in S. Buchholz and D. Hofaecker (eds), The Flexibilization of European Labor Markets: The Development of Social Inequalities in an Era of Globalization, Cheltenham, UK/Northampton, MA: Edward Elgar, pp.108-146.

Barbieri, P. and Bison, I. (2004) 'Self-employment in Italy: scaling the class barriers', in W. Müller and R. Arum (eds), Self-employment in advanced societies, Princeton, US: Princeton University Press, pp. 121-173.

Barbieri, P. and Cutuli, G. (2010) 'A uguale lavoro paghe diverse; Differenziali salariali e lavoro a termine nel mercato del lavoro italiano', Stato e Mercato 4: 471-504.

Barbieri, P. and Scherer, S. (2008) 'Increasing Labor Market Instability? The case of Italy', in H.P Blossfeld, S. Buchholz, E. Bukodi and K. Kurz (eds), Young Workers Globalization and the Labor Market: Comparing Early Working Life in Eleven Countries, Cheltenham, UK: Edward Elgar, pp. 155180.

Barbieri, P. and Scherer, S. (2009) 'Labor market flexibilisation and its consequences in Italy', European Sociological Review, 25(6): 677-692.

Barbieri, P., Cutuli G., Lugo, M. and Scherer, S. (2014) Italy: A Segmented Labor Market with Stratified Adult Learning: 327-347. In H.P. Blossfeld, E. Kilpi-Jakonen, D.Vono de Vilhena and S. Buchholz (eds), Adult Learning in Modern Societies: An International Comparison from a Life-Course Perspective. eduLIFE Lifelong Learning Series. Cheltenham, UK and Northampton, MA, USA: Edward Elgar. 
Bentolila, S., Dolado, J. J., Franz, W. and Pissarides, C. (1994) 'Labour flexibility and wages: lessons from Spain’, Economic policy, 9 (18): 53-99.

Bernardi, F. and Nazio, T. (2005) 'Globalization and the transition to adulthood in Italy', in H.P. Blossfeld, E. Klijzing, M. Mills and K. Kurz (eds), Globalization Uncertainty and Youth in Society, London, UK: Routledge, pp. 347-372.

Billari, F.C. (2008) 'Lowest-low fertility in Europe: Exploring the causes and finding some surprises', The Japanese Journal of Population 6(1): 2-18.

Blanchard, O. and Landier, A. (2002). The Perverse Effects of Partial Labor Market Reform: Fixed Duration Contracts in France, The Economic Journal, 112 (480).

Blossfeld, H.P. and Timm, A. (2003) Who marries whom? Educational systems as marriage markets in modern societies, Dordrecht, NL: Kluwer Academic.

Blossfeld, H.P., Buchholz, S., Bukodi, E. and Kurz, K. (eds) (2008) Young Workers, Globalization and the Labor Market. Comparing Early Working Life in Eleven Countries, Cheltenham, UK: Edward Elgar.

Blossfeld, H.P., Golsch, K. and Rohwer, G. (2007) Event history analysis with Stata, Mahwah, NJ: Lawrence Erlbaum Associates.

Blossfeld, H.P., Klijzing, E., Mills, M. and Kurz, K. (eds) (2005) Globalization Uncertainty and Youth in Society The Losers in a Globalizing World. Oxon (OX), UK: Routledge.

Bratti M., Tatsiramos K. (2012) The effect of delaying motherhood on the second childbirth in Europe, The Journal of Population Economics, 25:291-321.

Cutuli, G. and Guetto, R. (2013) 'Fixed-Term Contracts Economic Conjuncture and Training Opportunities: A Comparative Analysis Across European Labour Markets', European Sociological Review 29(3): 616-629.

Daly M. (2013) What Adult Worker Model? A Critical Look at Recent Social Policy Reform in Europe from a Gender and Family Perspective, in Pierson C. Castles F.G. Naumann I.K. (2013) The Welfare State Reader, Oxford University Press, Oxford

Davia, M.A. (2004) 'Temporary employment and segmentation in the Spanish labour market: An empirical analysis through the study of wage differentials', Spanish Economic Review 6: 291-318.

de la Rica, S. and Iza, A. (2005) 'Career Planning in Spain: Do Fixed-term Contracts Delay Marriage and Parenthood?', Review of Economics of the Household, 3: 49-73.

Del Boca, D. and Wetzels, C. (eds) (2007) Social Policies Labour Markets and Motherhood. Cambridge, UK: University Press Cambridge. 
Esping-Andersen, G. (1999) Social foundation of postindustrial economies, Oxford-New York: Oxford University Press.

Esping-Andersen, G. and Regini M. (eds) (2000) Why deregulate labour markets?, New York, US: Oxford University Press.

Esping-Andersen, G. and Sarasa, S. (2002) 'The Generational Contract Reconsidered', Journal of European Social Policy 12: 5-21.

Esping-Andersen G., Boertien D., Bonke . and Gracia P. (2013) Couple Specialization in Multiple Equilibria, European Sociological Review, vol. 29 n.6, 1280-1294

Ferrera, M. (2010) ‘The South European countries?', in F.G Castles, S. Leibfried, J. Lewis, H. Obinger and C. Pierson (eds), The Oxford handbook of the welfare state, Oxford, UK: Oxford University Press, pp.616-629.

Frejka, T. and Sobotka, T. (2009) 'Overview Chapter 1: Fertility in Europe: Diverse delayed and below replacement' Demographic Research 19(3): 195220.

Friedman, D., Hechter, M. and Kanazawa, S. (1994) 'A Theory of the Value of Children', Demography, 31(3): 375-401.

Gauthier, A.H. (2007) 'The impact of family policies on fertility in industrialized countries: a review of the literature', Population Research and Policy Review 26: $323-346$.

Golsch, K. (2003) 'Employment flexibility in Spain and its impact on transitions to adulthood', Work Employment and Society 17(4): 691-718.

González, M. (2006) 'Balancing employment and family responsibilities in southern Europe: trends and challenges for social policy reform', RFAS 5: 189-214.

González, M.J. and Jurado-Guerrero, T. (2007) 'Is There a Minimum Set of Conditions for Having a Baby? The Experience of the 1955 - 1982 Female Cohort in West Germany France Italy and Spain', in G. Esping-Andersen (ed.), Family Formation and Family Dilemmas in Contemporary Europe, Barcelona: Fùndaciòn BBVA, pp. 33-92.

Gutiérrez-Domènech, M. (2006) 'The impact of the labour market on the timing of marriage and births in Spain', Journal of Population Economics 21: 83110.

Hoem, J.M. and Kreyenfeld, M. (2006) 'Anticipatory analysis and its alternatives in life-course research Part 1: Education and first childbearing', MPIDR Working Papers 15: 461-484.

Keck, W. and Saraceno, S. (2013). The Impact of Different Social-Policy Frameworks on Social Inequalities among Women in the European Union: The Labour-Market Participation of Mothers, Social Politics, 20 (3): 297-328. 
Keck, W. and Saraceno, S. (2010). Can we identify intergenerational policy regimes in Europe? European Societies, 12 (5): 675-696.

Kreyenfeld, M. (2010) 'Uncertainties in female employment careers and the postponement of parenthood in Germany', European Sociological Review 26(3), 351-366.

Martín-García, T. (2013) Romulus and Remus or Just Neighbours? A Study of Demographic Changes and Social Dynamics in Italy and Spain, Population Review - Special collection 4 http://populationreview.com/special-collection$\underline{4}$

Mayer, K. U. (2004) 'Whose lives? How history, societies and institutions define and shape life courses', Research in Human Development 1(3): 161-187.

Naldini, M., Jurado, T. (2013). Family and Welfare State Reorientation in Spain and Inertia in Italy" Population Review, 54 (1): 43-61.

Oppenheimer, V.K., Kalmijn M. and Lim, N. (1997) 'Men's career development and marriage timing during a period of rising inequality', Demography 34(3): 311-330.

Pampel, F. (1994) 'Population aging, class context, and age inequality in public spending', American Journal of Sociology 100(1): 153-95.

Polavieja, J.G. (2003) 'Temporary Contracts and Labor Market Segmentation in Spain: An Employment-Rent Approach', European Sociological Review 19(5): 501-517.

Polavieja, J.G. (2005) 'The Incidence of Temporary Employment in Advanced Economies: Why is Spain Different?', European Sociological Review 22(1): 61-78.

Rindfuss, R.R. and Brewster, K.L. (1996) 'Childrearing and fertility', Population and Development Review 22: 258-289.

Rosolia, A. and Torrini, R. (2007) 'The generation gap: Relative earnings of young and old workers in Italy', Temi di discussione n.639, Banca d'Italia, http://www.bancaditalia.it/pubblicazioni/econo/temidi/td07/td639 07/td639/ en tema 639.pdf

Saraceno C., Keck W. (2011) Towards an integrated approach for the analysis of gender equity in policies supporting paid work and care responsibilities, Demographic Research, vol.25, art. 11, pp. 371-406.

Scherer, S. and Reyneri, E. (2008) 'Come è cresciuta l'occupazione femminile in Italia: fattori strutturali e culturali a confronto', Stato e Mercato 84: 183-213.

Sleebos, J. (2003) 'Low fertility rates in OECD countries: Facts and policy responses', OECD Labor Market and Social Policy Occasional Papers, http://www.oecd.org/els/emp/16587241.pdf 
Smeeding, T.M., Moynihan, D.P. and Rainwater, L. (2004) 'The challenge of family system changes for research and policy', in: D.P- Moynihan, T.M. Smeeding and L. Rainwater (eds), The future of the family, New York: Russell Sage Foundation, pp. 1-21.

Vandecasteele, L. (2011) 'Life Course Risks or Cumulative Disadvantage? The Structuring Effect of Social Stratification Determinants and Life Course Events on Poverty Transitions in Europe', European Sociological Review 27(2): 246-264.

Vignoli, D., Drefahl, S., and De Santis, G. (2012) 'Whose job instability affects the likelihood of becoming a parent in Italy? A tale of two partners' Demographic Research 26(2): 41-62.

Yamaguchi, K. (1991) Event history analysis, Newbury Park, CA: Sage Publications. 


\section{TABLES}

TABLE 1. Transition to motherhood. Discrete time model

\begin{tabular}{|c|c|c|c|c|c|c|}
\hline & \multicolumn{3}{|c|}{ Italy } & \multicolumn{3}{|c|}{ Spain } \\
\hline & M1 & M2 & M3 & M1 & M2 & M3 \\
\hline Age & $0.10 * * *$ & $0.10 * * *$ & $0.08 * * *$ & $0.08 * * *$ & $0.08 * * *$ & $0.05 * * *$ \\
\hline Age squared & $-0.00 * * *$ & $-0.00 * * *$ & $-0.00 * * *$ & $-0.00 * * *$ & $-0.00 * * *$ & $-0.00 * * *$ \\
\hline \multicolumn{7}{|l|}{$\begin{array}{l}\text { Birth cohorts (ref: } 1951- \\
\text { 55) }\end{array}$} \\
\hline $1956-60$ & 0.03 & 0.03 & 0.10 & $0.28 * * *$ & $0.26 * * *$ & 0.13 \\
\hline $1961-65$ & $-0.22 *$ & $-0.20 *$ & -0.04 & $0.20 * *$ & $0.17 * *$ & 0.03 \\
\hline $1966-70$ & $-0.44 * * *$ & $-0.42 * * *$ & -0.10 & $-0.01 *$ & -0.04 & $-0.17 * *$ \\
\hline $1971-80$ & $-1.26 * * *$ & $-1.16^{* * *}$ & $-0.76 * * *$ & $-0.35 * * *$ & $-0.36 * * *$ & $-0.47 * * *$ \\
\hline \multirow{2}{*}{\multicolumn{7}{|c|}{$\begin{array}{l}\text { Level of education } \\
\text { (ref: } \text { Casmin =1) }\end{array}$}} \\
\hline & & & & & & \\
\hline Casmin $=2$ & $-0.86 * * *$ & $-0.67 * * *$ & $-0.44 * * *$ & $-0.42 * * *$ & -0.06 & $-0.13 *$ \\
\hline Casmin $=3$ & $-1.22 * * *$ & $-0.53 * * *$ & -0.02 & $-1.02 * * *$ & $-0.36 * * *$ & $-0.29 * * *$ \\
\hline $\begin{array}{l}\text { Out of educational } \\
\text { system }\end{array}$ & $0.72 * * *$ & $0.56^{* * *}$ & $0.55^{* * *}$ & $0.49 * * *$ & $0.46^{* * *}$ & $0.40 * * *$ \\
\hline \multicolumn{7}{|l|}{ Work arrangement } \\
\hline \multicolumn{7}{|l|}{ (ref: Permanent work) } \\
\hline Self-Employed & -0.11 & -0.01 & -0.03 & $0.25 * *$ & $0.33 * * *$ & 0.22 \\
\hline Atypical contracts & $-0.26 * *$ & -0.26 & -0.16 & $-0.34 * * *$ & -0.05 & -0.05 \\
\hline Other & $-0.31 * * *$ & $-0.34 * * *$ & -0.08 & $0.43 * * *$ & $0.49 * * *$ & $0.45^{* * *}$ \\
\hline Out of work & 0.12 & $0.19 *$ & 0.15 & $0.18 * *$ & $0.44 * * *$ & $0.23 * *$ \\
\hline \multicolumn{7}{|l|}{$E G P($ ref: $V+V I+V I I)$} \\
\hline $\mathrm{I}+\mathrm{II}$ & $0.78 * * *$ & 0.33 & 0.15 & $0.80 * * *$ & $0.45 * * *$ & $0.26^{*}$ \\
\hline IIIa & $0.37 * * *$ & 0.15 & 0.07 & $0.39 * * *$ & $0.31 * * *$ & $0.22 * *$ \\
\hline $\mathrm{IIIb}$ & $-0.20 *$ & $-0.24 * *$ & -0.15 & 0.09 & 0.08 & 0.04 \\
\hline IV & -0.06 & -0.21 & -0.24 & 0.06 & -0.05 & -0.26 \\
\hline $\begin{array}{l}\text { Transition to secure } \\
\text { work }\end{array}$ & $0.43 * * *$ & $0.39 * * *$ & $0.39 * * *$ & $0.11 *$ & 0.05 & $0.09 *$ \\
\hline Unempl. rate (15-24) & $-0.03 * * *$ & $-0.03 * * *$ & $-0.03 * * *$ & $-0.02 * * *$ & $-0.02 * * *$ & $-0.01 * * *$ \\
\hline Have a partner & & & $2.25 * * *$ & & & $1.93 * * *$ \\
\hline \multicolumn{7}{|l|}{ Interactions: } \\
\hline Atypical*1971-80 & & $-2.11 * * *$ & $-2.27 * * *$ & & -0.05 & -0.03 \\
\hline Atypical $*$ casmin $=2$ & & 0.39 & 0.30 & & $-0.70 * * *$ & $-0.59 * * *$ \\
\hline Atypical $*$ casmin $=3$ & & -0.17 & $-0.47 * *$ & & $-0.91 * * *$ & $-0.81 * * *$ \\
\hline Out of work $*$ casmin $=2$ & & $-0.31 * *$ & -0.18 & & $-0.50 * * *$ & $-0.40 * * *$ \\
\hline Out of work $*$ casmin $=3$ & & $-1.43 * * *$ & $-1.27 * * *$ & & $-1.09 * * *$ & $-0.92 * * *$ \\
\hline Constant & $-20.22 * * *$ & $-20.42 * * *$ & $-16.48 * * *$ & $-17.26 * * *$ & $-17.41 * * *$ & $-13.47 * * *$ \\
\hline Number of subjects & 2,952 & 2,952 & 2,952 & 4,702 & 4,702 & 4,702 \\
\hline Observations & 417,365 & 417,365 & 417,365 & 680,272 & 680,272 & 680,272 \\
\hline
\end{tabular}

$* * * \mathrm{p}<0.01, * * \mathrm{p}<0.05, * \mathrm{p}<0.1$

Note: Models control also for: birth zone, number of siblings, and missing data 
TABLE 2. Effects of partner's working position (selected coefficients). Women with a partner at t-2. Discrete time models (Italy and Spain)

\begin{tabular}{|c|c|c|c|c|}
\hline & \multicolumn{4}{|c|}{ Only women with a partner at $\mathrm{t}-12$} \\
\hline & \multicolumn{2}{|c|}{ Italy } & \multicolumn{2}{|c|}{ Spain } \\
\hline & M1 & M2 & M1 & M2 \\
\hline \multicolumn{5}{|l|}{$\begin{array}{l}\text { Partner's work arrangement } \\
\text { (ref: permanent work) }\end{array}$} \\
\hline Self-employed & & -0.02 & & -0.16 \\
\hline Atypical work & & -0.24 & & -0.14 \\
\hline Other & & $0.42 * *$ & & 0.13 \\
\hline Out of work & & $-0.49^{* *}$ & & $-0.33 * * *$ \\
\hline No info & & -0.12 & & $-0.69 * * *$ \\
\hline \multicolumn{5}{|l|}{ Partner's EGP $(V+V I+V I I)$} \\
\hline I+II & & -0.14 & & 0.00 \\
\hline IIIa & & 0.01 & & -0.07 \\
\hline IIIb & & -0.22 & & 0.06 \\
\hline IV & & 0.08 & & 0.08 \\
\hline \multicolumn{5}{|l|}{ Women: } \\
\hline \multicolumn{5}{|l|}{ Level of education (ref: } \\
\hline \multicolumn{5}{|l|}{ Casmin $=1$ ) } \\
\hline Casmin $=2$ & $-0.22 *$ & -0.20 & -0.02 & -0.01 \\
\hline Casmin $=3$ & $0.41 * *$ & $0.45 * *$ & -0.07 & -0.06 \\
\hline \multicolumn{5}{|l|}{ Work arrangements (ref: } \\
\hline \multicolumn{5}{|l|}{ permanent employment) } \\
\hline Self-Employed & 0.20 & 0.24 & -0.01 & -0.02 \\
\hline Atypical contracts & 0.18 & 0.31 & -0.16 & -0.19 \\
\hline Other & 0.01 & -0.01 & -0.11 & -0.04 \\
\hline Out of work & -0.02 & -0.01 & -0.06 & -0.06 \\
\hline No info on the timing & & & 0.06 & 0.08 \\
\hline \multicolumn{5}{|l|}{$E G P(r e f: V+V I+V I I)$} \\
\hline $\mathrm{I}+\mathrm{II}$ & -0.10 & -0.07 & 0.03 & 0.06 \\
\hline IIIa & 0.06 & 0.08 & 0.07 & 0.10 \\
\hline IIIb & -0.10 & -0.09 & -0.02 & -0.01 \\
\hline IV & -0.43 & -0.47 & -0.20 & -0.17 \\
\hline Transition to stable employment & $0.43 * *$ & $0.43 * * *$ & $-0.21 * *$ & $-0.23 * *$ \\
\hline \multicolumn{5}{|l|}{ Interactions (women): } \\
\hline Atypical*1971-80 & $-2.59 * * *$ & $-2.60 * * *$ & -0.04 & -0.04 \\
\hline Atypical $*$ casmin $=2$ & 0.55 & 0.44 & $-0.38 * *$ & $-0.35^{*}$ \\
\hline Atypical*casmin=3 & $-0.48 * *$ & $-0.58 * *$ & $-0.74 * * *$ & $-0.77 * * *$ \\
\hline Out of work $*$ casmin $=2$ & 0.09 & 0.11 & $-0.41 * * *$ & $-0.39 * * *$ \\
\hline Out of work $*$ casmin $=3$ & $-0.42 * *$ & $-0.36^{* *}$ & $-0.70 * * *$ & $-0.66 * * *$ \\
\hline Constant & $-8.70 * * *$ & $-8.88 * * *$ & $-7.77 * * *$ & $-6.94 * * *$ \\
\hline Number of subjects & 1,257 & 1,257 & 2,757 & 2,757 \\
\hline Observations & 44,656 & 44,656 & 111,306 & 111,306 \\
\hline
\end{tabular}

*** $\mathrm{p}<0.01,{ }^{* *} \mathrm{p}<0.05,{ }^{*} \mathrm{p}<0.1$

Note: Models controls for age, age squared, zone, number of siblings, and missing data. 
TABLE 3. Family situation at age 30 - Simultaneous probit model - Only women with at least one job episode before age 30

\begin{tabular}{|c|c|c|c|c|c|}
\hline \multirow[t]{2}{*}{ Italy } & $\begin{array}{c}\text { Have } \\
\text { child(ren) }\end{array}$ & $\begin{array}{c}\text { Have a } \\
\text { partner }\end{array}$ & \multirow[t]{2}{*}{ Spain } & $\begin{array}{c}\text { Have } \\
\text { child(ren) }\end{array}$ & $\begin{array}{c}\text { Have a } \\
\text { partner }\end{array}$ \\
\hline & $b$ & $b$ & & $b$ & $b$ \\
\hline "Entrapped" & $-0.24 * *$ & $-0.25 * *$ & "Entrapped" & $-0.44 * * *$ & -0.14 \\
\hline Labor Market & & & Labor Market & & \\
\hline Entry & & & Entry & & \\
\hline (ref: before & & & (ref: before & & \\
\hline 1985) & & & 1985) & & \\
\hline $1985-97$ & $-0.65 * * *$ & $-0.41 * * *$ & $1985-97$ & $-0.39 * * *$ & -0.08 \\
\hline after 1998 & $-1.24 * * *$ & $-0.69 * * *$ & after 1998 & $-0.83 * * *$ & $-0.26 *$ \\
\hline Constant & $0.61 * *$ & $0.94 * * *$ & Constant & $0.78 * * *$ & $0.58 * * *$ \\
\hline \multicolumn{3}{|c|}{ N. $=1,537$ rho $=0.89(0.02)$} & \multicolumn{3}{|c|}{$\mathrm{N} .=2,317 \quad$ rho $=0.62(0.03)$} \\
\hline
\end{tabular}

Note: models control for age, education, social class and region of residence, all measured at first job.

TABLE 4. Family situation at age 30.

Predicted probabilities and c.i. (based on models in table 3)

\begin{tabular}{|c|c|c|c|c|c|c|c|}
\hline \multicolumn{4}{|c|}{ Italy } & \multicolumn{4}{|c|}{ Spain } \\
\hline $\begin{array}{r}\mathrm{Fa} \\
\text { arra }\end{array}$ & $\begin{array}{l}\text { nily } \\
\text { gement }\end{array}$ & & & $\begin{array}{r}\mathrm{Fa} \\
\text { arra }\end{array}$ & $\begin{array}{l}\text { nily } \\
\text { gement }\end{array}$ & & \\
\hline Partner & $\begin{array}{c}\text { Child(re } \\
\text { n) }\end{array}$ & $\begin{array}{c}\text { "Entrappe } \\
\text { d" }\end{array}$ & $\begin{array}{l}\text { Stable } \\
\text { career }\end{array}$ & Partner & $\begin{array}{c}\text { Child(re } \\
\text { n) }\end{array}$ & $\begin{array}{c}\text { "Entrappe } \\
\text { d" }\end{array}$ & $\begin{array}{l}\text { Stable } \\
\text { career }\end{array}$ \\
\hline yes & yes & $\begin{array}{c}0.41 \\
{[0.38-0.44]}\end{array}$ & $\begin{array}{c}0.58 \\
{[0.57-0.59]}\end{array}$ & yes & yes & $\begin{array}{c}0.39 \\
{[0.37-0.42]}\end{array}$ & $\begin{array}{c}0.53 \\
{[0.52-0.54]}\end{array}$ \\
\hline yes & no & $\begin{array}{c}0.17 \\
{[0.15-0.18]}\end{array}$ & $\begin{array}{c}0.13 \\
{[0.13-0.14]}\end{array}$ & yes & no & $\begin{array}{c}0.30 \\
{[0.29-0.32]}\end{array}$ & $\begin{array}{c}0.20 \\
{[0.19-0.20]}\end{array}$ \\
\hline no & yes & $\begin{array}{c}0.03 \\
{[0.02-0.03]}\end{array}$ & $\begin{array}{c}0.03 \\
{[0.03-0.03]}\end{array}$ & no & yes & $\begin{array}{c}0.04 \\
{[0.04-0.05]}\end{array}$ & $\begin{array}{c}0.07 \\
{[0.07-0.07]}\end{array}$ \\
\hline no & no & $\begin{array}{c}0.40 \\
{[0.37-0.42]}\end{array}$ & $\begin{array}{c}0.26 \\
{[0.25-0.27]}\end{array}$ & no & no & $\begin{array}{c}0.25 \\
{[0.23-0.27]}\end{array}$ & $\begin{array}{c}0.19 \\
{[0.18-0.19]}\end{array}$ \\
\hline
\end{tabular}




\section{FIGURES}

FIGURE 1. Predicted probabilities to become mother - discrete time model

Table 1 - M3

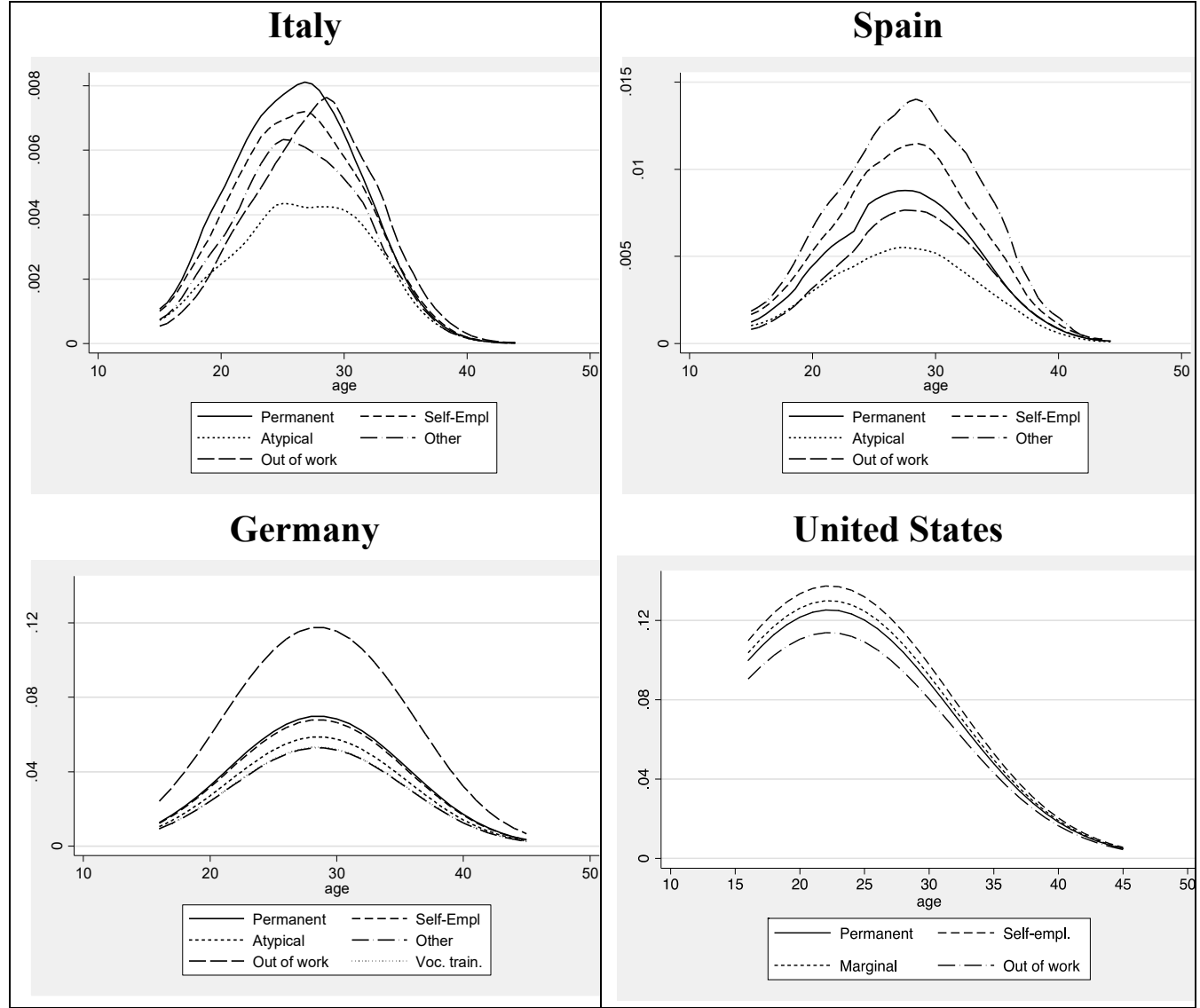

Source: ILFI, FVE, G-SOEP, PSID. Predicted probabilities based on multivariate discrete time duration model (see table 1 and table 1-A for details). Please note the different scales of the graphs (monthly for Italy and Spain, annual for Germany and the United States). 


\section{ADDITIONAL MATERIAL}

For the US the distinction between different work contracts is quite meaningless given the overall employment legislation. We therefore opted for an alternative definition to capture "atypical or outsider market positions". Scholars have argued that in U.S. the association between part-time jobs and bad jobs is particularly strong (Kalleberg et al. 2000), the definition of "marginal work "is based on part-time workers with an hourly pay less than two third of the median pay employed in firms characterized by the absence of trade unions.

For Germany, atypical employment includes just fixed-term contracts. The 'Other' category contains the so-called marginal jobs (including the now 'famous' mini-jobs) with less than 15 working hours a week. Our results are robust to different definitions of 'atypical employment'. Apprenticeship contracts are treated as a separate category.

In both countries models do not control for the number of siblings at 14.

TABLE A.2. Transition to motherhood. Discrete time model - United States and Germany

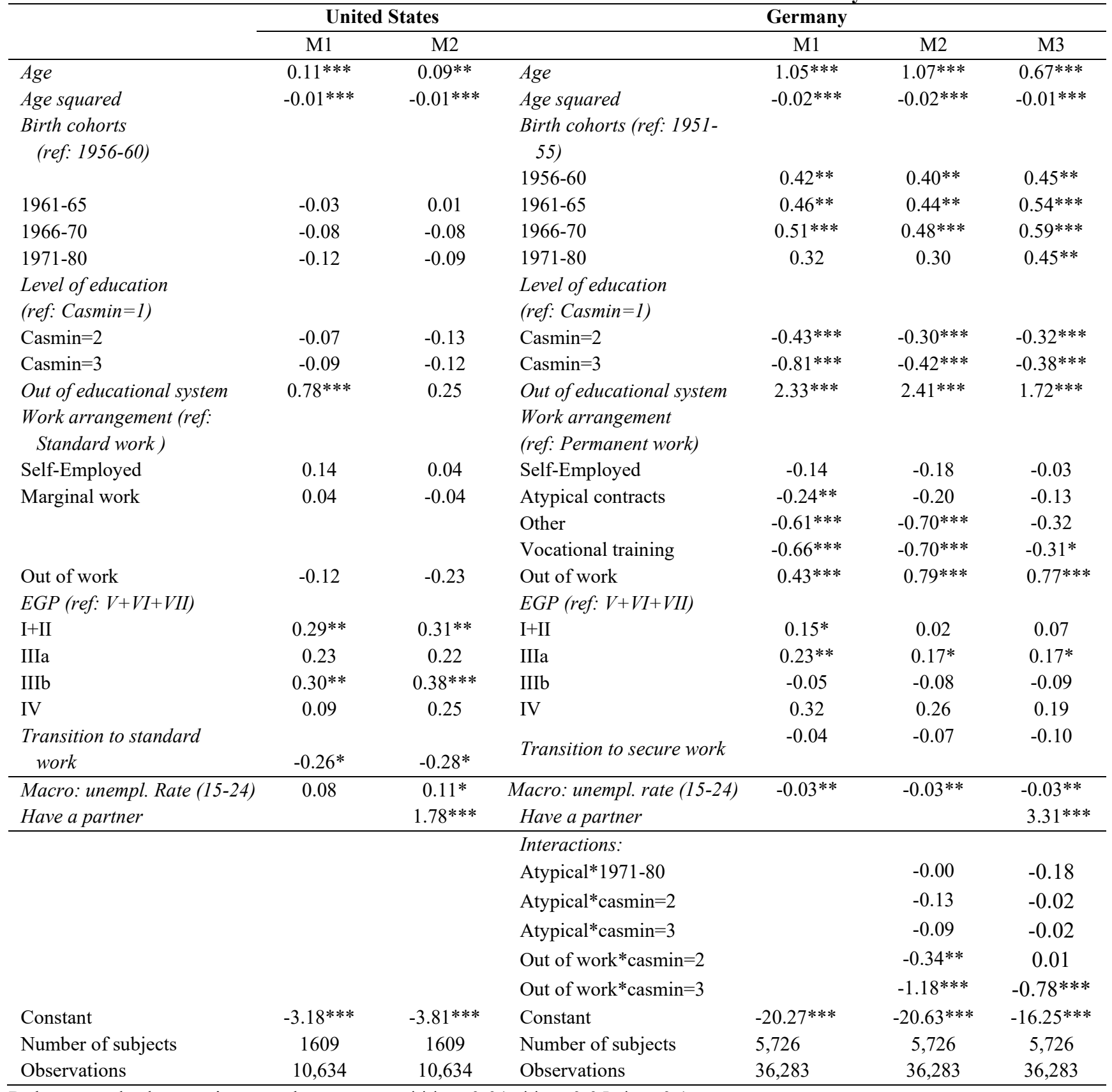

Robust standard errors in parentheses $\quad * * * \mathrm{p}<0.01, * * \mathrm{p}<0.05, * \mathrm{p}<0.1$

Note: Models control also for region in DE and race in the US and for missing data 
TABLE 2.2-A. Effects of partner's working position (selected coefficients) - only women with partner at t-2 Discrete time models

\begin{tabular}{|c|c|c|c|c|c|}
\hline & \multicolumn{2}{|c|}{ United States } & & \multicolumn{2}{|l|}{ Germany } \\
\hline & M1 & M2 & & M1 & M2 \\
\hline Partner's work arrangement & & & Partner's work arrangement & & \\
\hline (ref: Standard work) & & & (ref: permanent work) & & \\
\hline Self-Employed & & 0.22 & Self-Employed & & -0.01 \\
\hline \multirow[t]{3}{*}{ Marginal work } & & -0.21 & Atypical work & & 0.14 \\
\hline & & & Other & & -0.02 \\
\hline & & & Vocational training & & $-0.78^{*}$ \\
\hline Out of work & & -0.05 & Out of work & & $0.51 * *$ \\
\hline No info & & $-0.70 * * *$ & No info & & -0.01 \\
\hline Partner's EGP & & & Partner's EGP & & \\
\hline (ref: $V+V I+V I I)$ & & & (ref: $V+V I+V I I)$ & & \\
\hline $\mathrm{I}+\mathrm{II}$ & & 0.08 & $\mathrm{I}+\mathrm{II}$ & & 0.08 \\
\hline IIIa & & 0.02 & IIIa & & -0.09 \\
\hline IIIb & & -0.07 & IIIb & & $-0.30^{*}$ \\
\hline IV & & 0.12 & IV & & 0.03 \\
\hline Women: & & & Women: & & \\
\hline Level of education & & & Level of education & & \\
\hline (ref: Casmin $=1)$ & & & $($ ref: Casmin $=1)$ & & \\
\hline Casmin $=2$ & 0.16 & 0.14 & Casmin $=2$ & -0.13 & -0.15 \\
\hline Casmin $=3$ & 0.35 & 0.32 & Casmin $=3$ & -0.13 & -0.19 \\
\hline Out of educational system & -0.08 & -0.10 & Out of educational system & $2.38 * *$ & $2.30 * *$ \\
\hline Work arrangement (ref: & & & Work arrangements (ref: & & \\
\hline Standard work) & & & Permanent work) & & \\
\hline Self-Employed & 0.02 & -0.08 & Self-Employed & 0.06 & 0.05 \\
\hline \multirow[t]{3}{*}{ Marginal work } & 0.09 & 0.07 & Atypical contracts & -0.38 & -0.35 \\
\hline & & & Other & $-0.58^{*}$ & $-0.62 * *$ \\
\hline & & & Vocational training & -0.50 & -0.46 \\
\hline Out of work & -0.11 & -0.10 & Out of work & $0.93 * * *$ & $0.75 * * *$ \\
\hline$E G P$ (ref: $V+V I+V I I)$ & & & $E G P(r e f: V+V I+V I I)$ & & \\
\hline $\mathrm{I}+\mathrm{II}$ & $0.46 * *$ & $0.39 * *$ & $\mathrm{I}+\mathrm{II}$ & 0.14 & 0.15 \\
\hline IIIa & $0.36^{*}$ & 0.31 & IIIa & 0.17 & 0.20 \\
\hline IIIb & $0.42 * *$ & $0.44 * *$ & IIIb & -0.05 & -0.02 \\
\hline IV & 0.66 & 0.60 & IV & 0.05 & 0.11 \\
\hline \multirow[t]{7}{*}{ Transition to standard work } & -0.25 & -0.23 & Transition to secure work & -0.15 & -0.14 \\
\hline & & & Interactions (women): & & \\
\hline & & & Atypical*1971-80 & -0.17 & -0.21 \\
\hline & & & Atypical $*$ casmin $=2$ & 0.06 & 0.12 \\
\hline & & & Atypical ${ }^{*}$ casmin $=3$ & 0.04 & 0.05 \\
\hline & & & Out of work $*$ casmin $=2$ & 0.25 & 0.19 \\
\hline & & & Out of work $*$ casmin $=3$ & $-0.51 *$ & $-0.53 *$ \\
\hline Constant & $-2.70 * * *$ & $-2.20 * * *$ & Constant & $-13.77 * * *$ & $-13.91 * * *$ \\
\hline Number of subjects & 1020 & 1020 & Number of subjects & 2,673 & 2,673 \\
\hline Observations & 4,298 & 4,298 & Observations & 10,061 & 10,061 \\
\hline
\end{tabular}

*** $\mathrm{p}<0.01, * * \mathrm{p}<0.05, * \mathrm{p}<0.1$, Robust standard errors in parentheses

Note: Models control also for age, age squared, region (in Germany), race (in USA), women's employment position, and missing data 
TABLE 3.2-A. Family situation at 30 - Simultaneous probit model - Only women with at least one job episode before age 30

\begin{tabular}{|c|c|c|c|c|c|}
\hline United States & $\begin{array}{l}\text { Have a } \\
\text { partner }\end{array}$ & $\begin{array}{c}\text { Have } \\
\text { child(ren) }\end{array}$ & Germany & $\begin{array}{l}\text { Have a } \\
\text { partner }\end{array}$ & $\begin{array}{c}\text { Have } \\
\text { child(ren) }\end{array}$ \\
\hline "Entrapped" & 0.26 & -0.20 & "Entrapped" & -0.02 & -0.01 \\
\hline \multicolumn{6}{|c|}{ Labor market entry (ref: before 1985) } \\
\hline $1985-97$ & $-0.23 * * *$ & -0.03 & $1985-97$ & $-0.24 * * *$ & $-0.38 * * *$ \\
\hline after 1998 & $-0.29 * * *$ & -0.11 & after 1998 & -0.11 & $-0.58 * * *$ \\
\hline Constant & $1.40 * * *$ & $1.90 * * *$ & Constant & $0.78 * *$ & $1.15^{* * *}$ \\
\hline Rho & \multicolumn{2}{|c|}{$0.53(0.04)$} & Rho & \multicolumn{2}{|c|}{$0.64(0.03)$} \\
\hline Observations & \multicolumn{2}{|c|}{2,172} & Obs. & \multicolumn{2}{|c|}{2,253} \\
\hline
\end{tabular}

$* * * \mathrm{p}<0.01, * * \mathrm{p}<0.05$, é $\mathrm{p}<0.1$

Note: models control for age and EGP measured at first job, and region (in DE), education and work arrangements. For Germany 'Entrapped' refers to both atypical contracts and marginal employment.

TABLE 4-A. Family situation at age 30. Predicted probabilities (based on table 3)

\begin{tabular}{|c|c|c|c|c|c|c|c|}
\hline \multirow{2}{*}{\multicolumn{2}{|c|}{$\begin{array}{c}\text { United States } \\
\text { Family arrangement } \\
\end{array}$}} & \multicolumn{6}{|c|}{ Germany } \\
\hline & & & & & & & \\
\hline Partner & Child(ren) & "Entrapped" & Stable career & Partner & Child(ren) & "Entrapped" & $\begin{array}{l}\text { Stable } \\
\text { career }\end{array}$ \\
\hline yes & yes & $\begin{array}{c}0.66 \\
{[0.62-0.70]}\end{array}$ & $\begin{array}{c}0.55 \\
{[0.54-0.55]}\end{array}$ & yes & yes & $\begin{array}{c}0.68 \\
{[0.63-0.70]}\end{array}$ & $\begin{array}{c}0.56 \\
{[0.55-0.57]}\end{array}$ \\
\hline yes & no & $\begin{array}{c}0.16 \\
{[0.12-0.21]}\end{array}$ & $\begin{array}{c}0.12 \\
{[0.12-0.13]}\end{array}$ & yes & no & $\begin{array}{c}0.14 \\
{[0.12-0.16]}\end{array}$ & $\begin{array}{c}0.22 \\
{[0.21-0.23]}\end{array}$ \\
\hline no & yes & $\begin{array}{c}0.10 \\
{[0.05-0.14]}\end{array}$ & $\begin{array}{c}0.21 \\
{[0.21-0.22]}\end{array}$ & no & yes & $\begin{array}{c}0.07 \\
{[0.06-0.07]}\end{array}$ & $\begin{array}{c}0.06 \\
{[0.05-0.06]}\end{array}$ \\
\hline no & no & $\begin{array}{c}0.08 \\
{[0.07-0.09]}\end{array}$ & $\begin{array}{c}0.12 \\
{[0.11-0.12]}\end{array}$ & no & no & $\begin{array}{c}0.12 \\
{[0.1-0.14]}\end{array}$ & $\begin{array}{c}0.16 \\
{[0.16-0.17]}\end{array}$ \\
\hline
\end{tabular}

